|| ISSN(online): 2589-8698 || ISSN(print): 2589-868X || International Journal of Medical and Biomedical Studies

Available Online at www.ijmbs.info

Volume 3, Issue 2; February: 2019; Page No. 20-25

PubMed (National Library of Medicine ID: 101738825)

Index Copernicus Value 2017: 40.03

\title{
ASSOCIATION OF HYPOTHYROIDISM AND ANEMIA- STUDY FROM A REGION OF JAMMU AND KASHMIR.
}

\author{
Jibran Amin ${ }^{1}$, Nusrat Bashir ${ }^{2}$, Tazeen Jeelani ${ }^{3}$, Nausrat Ali $^{4}$, Bilal Musharaf Banday $^{5}$ \\ Department of Pathology Government Medical College Srinagar J\&K India.
}

Article Info: Received 12 January 2019; Accepted 07 February. 2019

Cite this article as: Amin, J., Bashir, N., Jeelani, T., Ali, N., \& Banday, B. M. (2019). ASSOCIATION OF

HYPOTHYROIDISM AND ANEMIA- STUDY FROM A REGION OF JAMMU AND KASHMIR. International Journal of

Medical and Biomedical Studies, 3(2).

DOI: https://doi.org/10.32553/ijmbs.v3i1.84

Address for Correspondence: Tazeen Jeelani, Department of Pathology Government Medical College Srinagar J\&K India.

Conflict of interest: No conflict of interest.

\section{Abstract}

Background: lodine deficiency is the most common cause of hypothyroidism worldwide. Anemia is often the first sign of hypothyroidism and it is often not diagnosed because hypothyroids have a lower volume of plasma which causes a false high estimation of the amount of haemoglobin in the blood. The anemia observed may be normocytic and normochromic, hypochromic and microcytic, or macrocytic.

Material methods: The study was conducted in the Postgraduate department of Pathology and Department of Medicine, Government Medical College Jammu, Jammu and Kashmir India. It was prospective study, extending over a period of one year from 1st October 2013 to 30th September 2014.

Results: Out of the 70 patients, 13 males were (18.57\%) and 57 were females (81.43\%) patients resulting in Male: Female ratio of $1: 4.4$, moreover $38(54.29 \%)$ patients presented as subclinical hypothyroidism while as 32(45.71\%) patients presented as overt hypothyroidism. Thus more cases of sub-clinical hypothyroidism were seen than overt hypothyroidism in our setting. . Over all grading of anemia in all 38 anemic hypothyroid patients irrespective of gender showed that most of the patients were in the category of moderate anemia (63.16\%).

Conclusion: and it was observed that 38 patients had anemia so, frequency of anemia in hypothyroid patients in our setup came out to be 54\%. Normocytic normochromic anemia (anemia of chronic disease) was the commonest type of anemia observed in $55.26 \%$ of anemic hypothyroid patients followed by macrocytic (21.05\%) and microcytic anemia (18.42\%).

Key words: Anemia, Hypothyroidism, Anemia of chronic disease, Microcytic hypochromic anemia.

\section{Introduction:}

Thyroid hormones play an important physiological role in humans. They regulate human hematopoiesis in the bone marrow (1). lodine deficiency is the most common cause of hypothyroidism worldwide. Permanent loss of thyroid or destruction of thyroid, through process such as autoimmune destruction or irradiation injury is described as primary hypothyroidism. Central or secondary hypothyroidism, due to insufficient stimulation of thyroid gland, is result of hypothalamic or pituitary disease or defects in thyroid stimulating hormone (TSH) molecule (2). In overt primary hypothyroidism the serum TSH concentration is 
elevated and the serum free thyroxine (T4) level is below the reference range, while in subclinical hypothyroidism an elevated serum TSH value is associated with a serum free $\mathrm{T} 4$ that is still within the reference range (3). Clinical features of adult hypothyroidism include Tiredness, weakness, Dry skin, Feeling cold, Hair loss, Difficulty in concentrating and poor memory, Constipation, Weight gain with poor appetite, Dyspnoea, Hoarse voice, Menorrhagia (later oligomenorrhea or amenorrhea), Paresthesia, Impaired hearing (4).

Anemia is often the first sign of hypothyroidism and it is often not diagnosed because hypothyroids have a lower volume of plasma which causes a false high estimation of the amount of haemoglobin in the blood (5). Anemia is observed in 21 to $60 \%$ of hypothyroid patients and is more common in hypothyroid men than in hypothyroid women. The anemia observed may be normocytic and normochromic, hypochromic and microcytic, or macrocytic (6). When patients with iron, folate, or vitamin B12 deficiency are excluded, the remaining individuals should be considered to have "uncomplicated anemia of hypothyroidism," which is a manifestation of the hormone deficiency itself (7). The degree of anemia is related to both the severity and the duration of the hypothyroidism (6). The anemia of hypothyroidism results from decreased red cell production. Erythrocyte survival is normal or even slightly prolonged in humans, but plasma iron transport and erythrocyte iron turnover rates are reduced, indicating subnormal red cell production (8).

\section{Material and methods:}

The study was conducted in the Postgraduate department of Pathology and Department of Medicine, Government Medical College Jammu, Jammu and Kashmir India. It was prospective study, extending over a period of one year from 1st October 2013 to 30th September 2014. The study was approved by ethical committee, Govt. Medical College Jammu.
Inclusion criteria: All newly diagnosed patients with hypothyroidism (subclinical/ overt) irrespective of age and gender were included in the study.

\section{Exclusion criteria:}

1. Multifactorial anemia including hemolytic anemia, gastrointestinal or genitourinary losses due to malignancy and/or acute/sub-acute blood losses from the respiratory gastrointestinal or genitourinary system.

2. Prior thyroid disorder and/or treatment history.

3. Presence of any comorbid disease like renal insufficiency/failure, coronary heart disease, uncontrolled hypertension, diabetes mellitus or any endocrine system disease other than hypothyroidism.

4. Patients under treatment that might affect blood parameters such as steroids or who had received anemia treatment previously.

All patients on whom the study was to be conducted, a proper consent from the patient / attendant was taken prior to the studies.

Complete blood Count was done using three part differential-Counter by sysmex. Detailed peripheral blood examination was carried out after staining the blood film by Romanowsky stains (Leishman/May Grunwald Giemsa stain).

Primary hypothyroidism was defined as $\mathrm{TSH}>4.0 \mu \mathrm{IU} / \mathrm{ml} \quad(0.4-4.0)$ and FT4 levels $<0.89 \mathrm{ng} / \mathrm{dl} \quad(0.89-1.76 \mathrm{ng} / \mathrm{dl})$, according to laboratory values in hospital. The method used for measuring TSH was chemilumininscence method.

\section{Results:}

During the study period, 105 hypothyroid patients were diagnosed, 35 patients were excluded from the study as they didn't meet the criteria. So, the main study was done on remaining 70 patients.

Out of the 70 patients, 13 males were $(18.57 \%)$ and 57 were females $(81.43 \%)$ patients resulting in Male: Female ratio of 1:4.4, moreover $38(54.29 \%)$ patients presented as subclinical hypothyroidism while as $32(45.71 \%)$ patients 
presented as overt hypothyroidism. Thus more cases of sub-clinical hypothyroidism were seen than overt hypothyroidism in our setting.

Among 38 subclinical cases $7(18.42 \%)$ were males and $31(81.58 \%)$ were females. Similarly among 32 overt cases, $6(18.75 \%)$ were males and 26(81.25\%) were females. The age distribution of the hypothyroid patients studied, ranged from 18 years to 65 years. However majority of patients were in the age group between 31 to 40 (32.86\%) years followed by the age group 41-50 (31.43\%).

Anemia according to WHO was defined as haemoglobin level of $<13 \mathrm{~g} / \mathrm{dl}$ in males and $<12$ $\mathrm{g} / \mathrm{dl}$ in females. Out of 70 hypothyroid patients, $38(54.29 \%)$ were having anemia i.e having decreased haemoglobin levels while 32 (45.71\%) were non-anemic i.e having normal haemoglobin levels. In the present study, out of 13 male patients, 1 (7.69\%) patient was having haemoglobin $<8.0 \mathrm{~g} / \mathrm{dl}, 4(30.77 \%)$ patients were having hemoglobin $8.0-10.9 \mathrm{~g} / \mathrm{dl}, 1(7.69 \%)$ patient was having hemoglobin $11.0-12.9 \%$ and 7 (53.85\%) patients were having haemoglobin $>13 \mathrm{~g} / \mathrm{dl}$. out of 57 female patients, $8(14.04 \%)$ patients were having haemoglobin $<8.0 \mathrm{~g} / \mathrm{dl}, 20$ (35.09\%) patients were having hemoglobin 8.0$10.9 \mathrm{~g} / \mathrm{dl}, 4$ (7.02\%) patients were having hemoglobin $11.0-11.9 \mathrm{~g} / \mathrm{dl}$ and 25 (43.86\%) patients were having haemoglobin $>12 \mathrm{~g} / \mathrm{dl}$. Over all grading of anemia in all 38 anemic hypothyroid patients irrespective of gender showed that most of the patients were in the category of moderate anemia (63.16\%).

Among 13 male patients, 6 (46.15\%) were anemic and among 57 female patients 32 (56.14\%) were anemic showing that the prevalence of anemia is more in females than males (Table-1).The mean PCV among the 38 subclinical cases was $35.61 \%$ with a standard deviation of 6.57 whereas the mean PCV among the 32 overt cases was $35.22 \%$ with a standard deviation of 6.16. The PCV ranged from $19 \%$ to $45 \%$ among subclinical cases and from $20 \%$ to $45 \%$ among overt hypothyroid cases. MCV, $\mathrm{MCH}$ and $\mathrm{MCHC}$ values varied from case to case. MCV value was a useful parameter in making diagnosis of iron deficiency anemia and megaloblastic anemia where MCV values were low and high respectively. In most of the patients with dual deficiency anemia MCV value was normal. The mean MCV in subclinical cases was $85.71 \mathrm{fl}$ with a standard deviation of 8.06 whereas in overt cases mean MVC was $84.66 \mathrm{fl}$ with a standard deviation of 7.31. Similarly the mean $\mathrm{MCH}$ was $28.32 \mathrm{pg}( \pm 2.04)$ and $28.19 \mathrm{pg}( \pm 1.93)$ in subclinical and overt hypothyroid cases respectively.

Anemia was classified on the basis of peripheral blood film and red cell indices and other biochemical investigations. In the subgroup analysis of the hypothyroid patients, the most frequently seen type of anemia was the Anemia of chronic disease in patients with subclinical and overt hypothyroidism. Among 20 patients of subclinical hypothyroidism $11(55 \%)$ were having anemia of chronic disease while among 18 overt hypothyroidism cases 10 (56\%) were having anemia of chronic disease (Table-2). A detailed PBF examination gave a vital clue towards the diagnosis in all the patients ranging from nutritional deficiency anemia to anemia secondary to underlying inflammatory pathology like iron deficiency anemia / megaloblastic anemia / dual deficiency anemia and Anemia of Chronic Disease respectively (Table-3).

All of the mentioned investigations were essential to study the type of anemia and various hematological alterations in hypothyroid patients. 
Table 1: Showing gender-wise distribution of anemia in hypothyroid patients.

\begin{tabular}{|l|l|l|l|}
\hline & \multicolumn{2}{|c|}{ Gender } & \\
\hline Anemia & Male $\mathbf{n}(\%)$ & Female $\mathbf{n}(\%)$ & Total $\mathbf{n}(\%)$ \\
\hline Present & $6(46.15 \%)$ & $32(56.14 \%)$ & $38(54.29 \%)$ \\
\hline Absent & $7(53.85 \%)$ & $25(43.86 \%)$ & $32(45.71 \%)$ \\
\hline Total & $13(100 \%)$ & $57(100 \%)$ & $70(100 \%)$ \\
\hline
\end{tabular}

Table 2: Showing cause of anemia in patients with subclinical and overt hypothyroidism.

\begin{tabular}{|c|c|c|c|c|c|c|}
\hline & \multicolumn{4}{|c|}{ Type of Anemia } \\
\hline & & & Iron Deficiency & Megaloblastic & ACD & Dual Deficiency \\
\hline \multirow{4}{*}{ 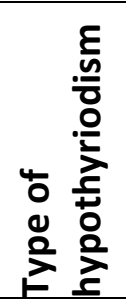 } & \multirow[b]{2}{*}{ subclinical } & $\mathrm{n}$ & 3 & 5 & 11 & 1 \\
\hline & & $\%$ & $15 \%$ & $25 \%$ & $55 \%$ & $5 \%$ \\
\hline & \multirow[t]{2}{*}{ overt } & $n$ & 4 & 3 & 10 & 1 \\
\hline & & $\%$ & $22.22 \%$ & $16.67 \%$ & $55.56 \%$ & $5.56 \%$ \\
\hline \multirow{2}{*}{\multicolumn{2}{|c|}{ TOTAL }} & $n$ & 7 & 8 & 21 & 2 \\
\hline & & $\%$ & $18.42 \%$ & $21.05 \%$ & $55.26 \%$ & $5.26 \%$ \\
\hline
\end{tabular}

Table 3: Detailed peripheral blood smear examination in 70 hypothyroid patients.

\begin{tabular}{|c|c|c|c|c|c|}
\hline PBF Detail & Impression & $\begin{array}{l}\text { No. of } \\
\text { patients }\end{array}$ & \% age & $\begin{array}{l}\text { Probable cause } \\
\text { of anemia }\end{array}$ & Remarks \\
\hline $\begin{array}{l}\text { Predominantly Normocytic blood } \\
\text { picture seen with normochromia. }\end{array}$ & Normal blood picture & 32 & $\begin{array}{l}45.71 \\
\%\end{array}$ & $\begin{array}{l}\text { No anemia } \\
\text { observed }\end{array}$ & $\begin{array}{l}\text { Non-anemic } \\
\text { hypothyroidism }\end{array}$ \\
\hline $\begin{array}{l}\text { Normocytic normochromic blood } \\
\text { picture, microcytes and mild } \\
\text { hypochromia seen in few cases. } \\
\text { Moderate rouleaux formation. }\end{array}$ & $\begin{array}{l}\text { Predominantly } \\
\text { Normocytic with } \\
\text { normochromia to } \\
\text { mild hypochromia }\end{array}$ & 21 & $\begin{array}{l}30 \\
\%\end{array}$ & $\begin{array}{l}\text { Anemia of } \\
\text { chronic disease }\end{array}$ & $\begin{array}{l}\text { Anemic } \\
\text { hypothyroidism }\end{array}$ \\
\hline $\begin{array}{l}\text { Moderate to severe aniso- } \\
\text { poikilocytosis. Macrocytes, macro- } \\
\text { ovalocytes seen. Hypersegemented } \\
\text { polymorphs and macropolycytes } \\
\text { seen. }\end{array}$ & $\begin{array}{l}\text { Predominantly } \\
\text { Macrocytic blood } \\
\text { picture with } \\
\text { pancytopenia and } \\
\text { leucoerythroblastosis } \\
\text { in some cases }\end{array}$ & 8 & $\begin{array}{l}11.42 \\
\%\end{array}$ & $\begin{array}{l}\text { Megaloblastic } \\
\text { anemia }\end{array}$ & $\begin{array}{l}\text { Anemia of } \\
\text { hypothyroidism }\end{array}$ \\
\hline $\begin{array}{l}\text { Moderate aniso-poikilocytosis. } \\
\text { Microcytic hypochromic } \\
\text { predominance, pencil cells and } \\
\text { target cells in some cases. }\end{array}$ & $\begin{array}{l}\text { Microcytic } \\
\text { hypochromic blood } \\
\text { picture/ dimorphic } \\
\text { blood picture }\end{array}$ & 7 & $10 \%$ & $\begin{array}{l}\text { Iron deficiency } \\
\text { anemia }\end{array}$ & $\begin{array}{l}\text { Anemia of } \\
\text { hypothyroidism }\end{array}$ \\
\hline $\begin{array}{l}\text { Moderate aniso-poikilocytosis. } \\
\text { Microcytes, macrocytes,ovalocytes } \\
\text { seen. Moderate to severe } \\
\text { hypochromia seen }\end{array}$ & $\begin{array}{l}\text { Dimorphic } \\
\text { picture }\end{array}$ & 2 & $\begin{array}{l}2.86 \\
\%\end{array}$ & $\begin{array}{l}\text { Dual deficiency } \\
\text { anemia }\end{array}$ & $\begin{array}{l}\text { Anemia of } \\
\text { hypothyroidism }\end{array}$ \\
\hline
\end{tabular}




\section{Discussion:}

The prevalence has been reported to be approximately $1-2 \%$ in women and $0.1 \%$ in men in large population studies (9). The presence of subclinical hypothyroidism is far higher, and reported to be about $4-10 \%$ in multiple populations (10). On the other hand, according to the data of WHO (World Health Organization), anemia is an important public health problem. In order to carry out the treatment of the patient with anemia correctly, it is necessary to determine etiological causes.

Majority of patients in our study were in the age group between 31 to 40 (32.86\%) years. The mean age of patients in this study was in accordance to a study by Iddah MA et al (11). There were 13 Male patients \& 57 female patients with a male:female ratio of 1:4.4 in the present study showing that hypothyroidism is more frequent in females than males which is supported by the literature. In a study conducted by Mitra $\mathrm{KJ}$ et al (12), male:female ratio was found to be1:4. Erdogan EM et al (13) found $13.5 \%$ hypothyroid patients to be males whereas $86.5 \%$ were females with a male: female ratio of 1:6.4. studies on prevalence of anemia in people with hypothyroidism generally define anemia by the World Health Organization (WHO) criteria. According to the data of WHO, anemia prevalence is $24.8 \%$ throughout the world and it is seen more frequently in developing countries. Anemia is diagnosed in $21-60 \%$ patients with hypothyroidism. Studies conducted by Tudhope et al, Horton et al and Dawson et al found 31\%, $26 \%$ and $53 \%$ hypothyroid patients to be anemic respectively $(14,6,15)$. In our study, anemia frequency in overt hypothyroid and subclinical hypothyroid groups was determined to be $56.25 \%$ and $52.63 \%$ respectively. The overall frequency was found to be $54.29 \%$. Thus, the frequency of anemia in subclinical hypothyroidism is as high as that in overt hypothyroidism. Anemia frequency in patients with overt hypothyroidism was found to be statistically insignificant when compared to subclinical group $(p=0.762)$.
In our study, among 6 male anemic patients (out of total 38 anemic patients), $7.69 \%$ had mild reduction in hemoglobin level, $30.77 \%$ had moderate and $7.69 \%$ had severe reduction in hemoglobin level. Hemoglobin level ranged from $7.8 \mathrm{~g} / \mathrm{dl}$ to $11.5 \mathrm{~g} / \mathrm{dl}$. Among 32 female anemic patients (out of total 38 anemic patients), 7.02\% had mild reduction in hemoglobin level, 35.09\% had moderate and $14.04 \%$ had severe reduction in hemoglobin level. Hemoglobin level ranged from $5.1 \mathrm{~g} / \mathrm{dl}$ to $11.8 \mathrm{~g} / \mathrm{dl}$. Our observation was consistent with studies carried by Iddah MA et al and Mitra KJ et al $(11,12)$.

In our study among the 38 anemic patients, $21(55.26 \%)$ patients were having predominantly normocytic blood picture, $8(21.05 \%)$ were having predominantly macrocytic blood picture, $4(10.53 \%)$ were having predominantly microcytic blood picture while 5 (13.26\%) were having dimorphic blood picture. Mitra KJ et al in their study found that out of 43 anemic hypothyroid patients $31(72 \%)$ were having normocytic blood picture, 5(11.63\%) were having macrocytic blood picture and $7(16.28 \%)$ were having microcytic blood picture (12). Most common type of anemia in the present study was anemia of chronic disease which was seen in $55 \%$ of subclinical hypothyroid patients and $55.56 \%$ of overt hypothyroid patients. Iron deficiency anemia was found to be present in $15 \%$ of subclinical hypothyroid patients and $22.22 \%$ of overt hypothyroid patients. Megaloblastic anemia was found to be in $25 \%$ and $16.67 \%$ of patient of subclinical and overt hypothyroid patients respectively. Mehmet et al found in their study that Anemia of chronic disease was seen in $61.5 \%$ and $72.1 \%$ of subclinical and overt anemic hypothyroid patients respectively. Iron deficiency anemia was seen in $15.4 \%$ and $11.16 \%$ of subclinical and overt cases respectively. Vitamin B12 deficiency was found in $25.6 \%$ and $18.6 \%$ of subclinical and overt cases respectively, and folic acid deficiency was seen in $2.6 \%$ and $4.6 \%$ cases respectively (16). 


\section{Conclusion:}

70 hypothyroid patients were studied for the period of one year and it was observed that 38 patients had anemia so, frequency of anemia in hypothyroid patients in our setup came out to be $54 \%$. Normocytic normochromic anemia (anemia of chronic disease) was the commonest type of anemia observed in $55.26 \%$ of anemic hypothyroid patients followed by macrocytic (21.05\%) and microcytic anemia (18.42\%).

Thyroid hormones have a significant influence on erythropoiesis. Anemia is frequently seen in these patients and it occurs as a result of various causes. Determination of etiological reasons of anemia and arrangement of the treatment is important.

\section{References:}

1. Kawa MP, Grymula K, Paczkowska E, et al. Clinical relevance of thyroid dysfunction in human haematopoiesis: biochemical and molecular studies. Eur J Endocrinol 2010; 162:295-305.

2. Brent GA, Larsen $P R$ and Davies TF. Hypothyroidism and Thyroiditis. In $\left(11^{\text {th }}\right.$ edition) Kronenberg HM, Melmed $\mathrm{S}$, Polonsky KS et al. Williams Textbook of Endocrinology 2008, $11^{\text {th }}$ edition Elsevier.pp.377.

3. Vanderpump MP, Tunbridge WM, French $\mathrm{JM}$, et al. The incidence of thyroid disorders in the community: a twenty year follow-up of the Whickham Survey. Clin Endocrinol 1995; 43:55-68.

4. Jameson JL. Endocrinology and Metabolism. In $\left(17^{\text {th }}\right.$ edition) Fausi AS, Braunwald E, Kasper DL et al. Harrison's Principles of Internal Medicine 2008, $17^{\text {th }}$ edn., vol 2, McGraw Hill.pp.2230.

5. Antonijevic N, Nesovic M, Trbojevic B, et al. Anemia in Hypothyroidism. Med Pregl 1999; 52,136-140.
6. Horton L, Coburn RJ, England JM, et al. The haematology of hypothyroidism. Q J Med 1976; 45,(177),101-123.

7. Robert T, Means JR. Anemias Secondary to Chronic Disease and Systemic Disorders. In:(12 ${ }^{\text {th }}$ edition) Greer JP, Foerster J, Rodgers GM et al. Wintrobe's Clinical Hematology 2009, 12th Edition, Lippincott Williams \& Wilkins.pp.1231.

8. Finch CA, Deubelbeiss K, Cook JD, et al. Ferrokinetics in man. Medicine 1970; 49:1753.

9. Helfand M and Redfern CC. Clinical Guideline Part 2: Screening for thyroid disease: An update. Ann Intern Med 1998; 129:144-58.

10. Hollowell JG, Staehling NW, Flanders WD, et al. Serum TSH, T4, \& thyroid antibodies in the United States population (1988 to 1994): National Health \& Nutrition Examination Survey (NHANESIII). J Clin Endocrinol Metab 2002; 87:489-99.

11. Iddah MA, Macharia BN, Ng'wena AG, et al. Thryroid Hormones and Hematological Indices Levels in Thyroid Disorders Patients at Moi Teaching and Referral Hospital, Western Kenya. ISRN Endocrinology 2013.

12. Mitra KJ, Ali SA, Seyed HS, et al. The Association between Hypothyroidism and Anemia: a clinical study. IJHOSCR, July 2010.

13. Erdogan Mehmet, Kosenli A, Sencer G, et al. Characteristics of anemia in subclinical and overt hypothyroid patients. Endocrine Journal 2012; 59(3):213-220.

14. Tudhope GR and Wilson GM. Anemia in hypothyroidism. Q J Med 1960; 29:513-538.

15. Dawson MA and Yarbo JW. Anemia in Hypothyroidism. South Med J 1970; 63:966970.

16. Erdogan Mehmet, Kosenli A, Sencer G, et al. Characteristics of anemia in subclinical and overt hypothyroid patients. Endocrine Journal 2012; 59(3):213-220. 